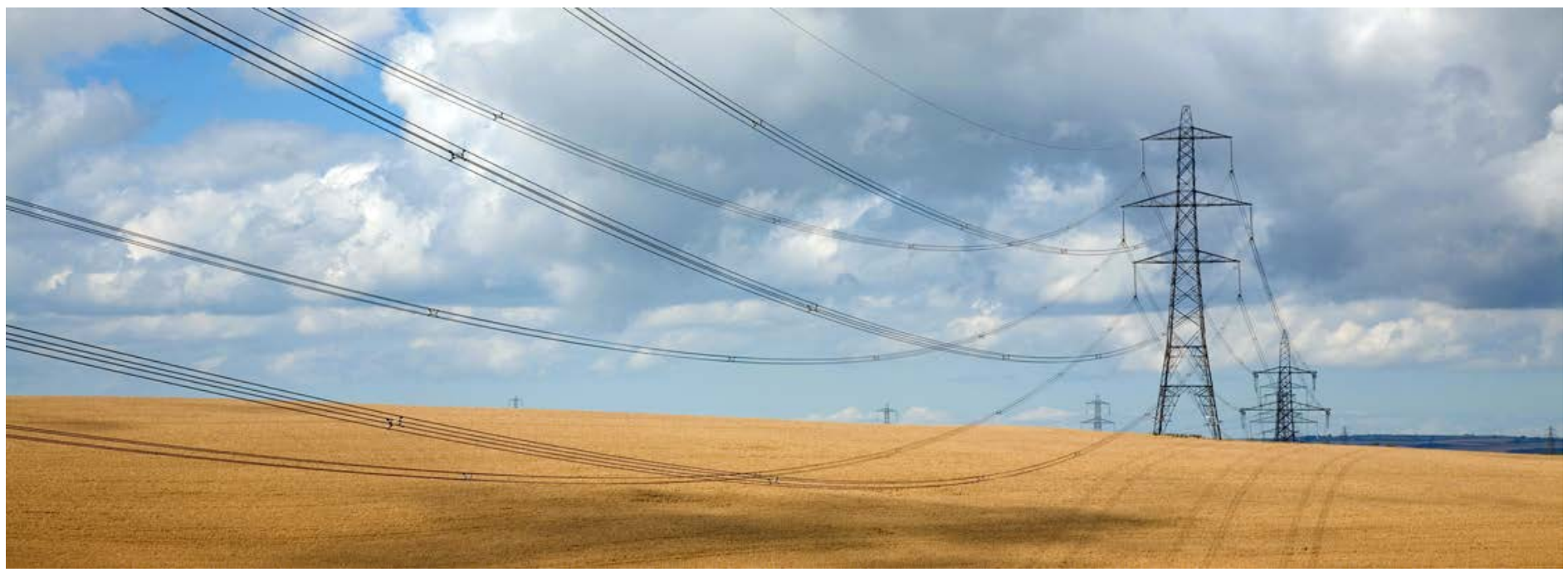

\title{
Military Base Off-taker Opportunities for Tribal Renewable Energy Projects
}

Prepared for the U.S. Department of Energy Office of Indian Energy Policy and Programs by the National Renewable Energy Laboratory

J. Nangle

National Renewable Energy Laboratory 


\section{NOTICE}

This report was prepared as an account of work sponsored by an agency of the United States government. Neither the United States government nor any agency thereof, nor any of their employees, makes any warranty, express or implied, or assumes any legal liability or responsibility for the accuracy, completeness, or usefulness of any information, apparatus, product, or process disclosed, or represents that its use would not infringe privately owned rights. Reference herein to any specific commercial product, process, or service by trade name, trademark, manufacturer, or otherwise does not necessarily constitute or imply its endorsement, recommendation, or favoring by the United States government or any agency thereof. The views and opinions of authors expressed herein do not necessarily state or reflect those of the United States government or any agency thereof.

Available electronically at www.osti.gov/bridge

Available for a processing fee to U.S. Department of Energy and its contractors, in paper, from:

U.S. Department of Energy

Office of Scientific and Technical Information

P.O. Box 62

Oak Ridge, TN 37831-0062

phone: 865.576 .8401

fax: 865.576 .5728

email: reports@adonis.osti.gov

Available for sale to the public, in paper, from:

U.S. Department of Commerce

National Technical Information Service

5285 Port Royal Road

Springfield, VA 22161

phone: 800.553 .6847

fax: 703.605.6900

email: orders@ntis.fedworld.gov

online ordering: www.ntis.gov/ordering.htm

energy.gov/indianenergy | indianenergy@hq.doe.gov

DOE/IE-0018 • May 2013

Printed with a renewable-source ink on paper containing at least $50 \%$ wastepaper, including $10 \%$ post consumer waste. 


\section{Acknowledgments}

This white paper is made possible by and at the direction of the U.S. Department of Energy (DOE) Office of Indian Energy Policy and Programs. The analysis was designed and carried out by John Nangle and informed by input from Anthony Lopez and Elizabeth Doris at the National Renewable Energy Laboratory (NREL). Tracey LeBeau and Pilar Thomas at the DOE Office of Indian Energy provided both specific comments and strategic direction.

\section{About the DOE Office of Indian Energy}

The U.S. Department of Energy Office of Indian Energy Policy and Programs was established by Congress to provide Tribes, Alaska Native villages, and eligible tribal entities with technical assistance to promote energy development and energy infrastructure on tribal lands.

In direct response to the requests of Tribes and Alaska Natives, the DOE Office of Indian Energy has designed key programs to provide Indian Country with the knowledge needed to make informed energy decisions-decisions with the power to help stabilize energy costs, enhance energy security, strengthen economic development and tribal energy infrastructure, and promote tribal self-determination.

By providing reliable, accurate information and expert technical assistance, the DOE Office of Indian Energy empowers Indian Country to make decisions needed to bring about the next generation of energy development on their lands.

The office supports those decisions by offering technical support related to technology and project development, financial assistance, and real-time training. It also works to advance tribal visions for a sustainable energy future by promoting four key goal areas: project development, job creation, grid infrastructure, and energy security. 


\author{
List of Abbreviations and Acronyms \\ Btu British thermal unit \\ CSP concentrating solar power \\ DOD Department of Defense \\ DSIRE Database of State Incentives for Renewable Energy \\ EPACT Energy Policy Act of 2005 \\ MMBtu million British thermal units \\ PV photovoltaic \\ RPS renewable portfolio standard \\ SUNY State University of New York \\ WECC Western Electricity Coordinating Council
}




\section{Executive Summary}

The U.S. Department of Defense (DOD) has set goals for greater consumption and procurement of renewable energy. These goals are informed by two pieces of legislation: the Energy Policy Act of 2005 (EPACT) and USC Title $10 \S 2911$ (e). As of Fiscal Year (FY) 2011, the DOD had achieved only 3.1\% of an FY 2011 EPACT goal of 5\% for total electrical consumption coming from renewable resources. In the same year, the DOD achieved only $8.5 \%$ of the USC 2911 goal stipulating that by $2025,25 \%$ of total energy be procured or generated renewable energy (Department of Defense 2012). These goals and policies illustrate the need for more renewable energy at military installations, as well as the opportunity for the military to partner with nearby landowners in developing renewable energy projects.

Tribal lands represent approximately $5 \%$ of the national renewable energy technical potential (Doris, Lopez, and Beckley 2013), and their close proximity to many DOD installations makes the Tribes potential partners in helping the DOD meet its renewable energy goals. The benefits to the Tribes include additional income streams and workforce development in green jobs.

This white paper surveys DOD installations that could have an interest in the purchase of energy from renewable energy projects on tribal lands. Tribes, in the right context, could supply local renewable energy to meet military demands, which would provide additional sources of energy to the installations, helping them meet federal requirements for renewable energy purchases and greenhouse gas reduction. Tribal members could benefit from additional income from land leases and energy sales, as well as workforce development and maintaining the renewable energy projects. Identification of likely purchasers of renewable energy is a first step in the energy project development process, and this paper aims to identify likely DOD electricity customers that tribal commercial-scale projects could serve. ${ }^{1}$

This white paper builds on a geospatial analysis completed in November 2012 identifying 53 reservations within 10 miles of military bases (DOE 2012). This analysis builds on those findings by further refining the list of potential opportunity sites to 15 reservations (Table ES-1), based on five additional factors:

1. The potential renewable resources required to meet the installation energy loads

2. Proximity to transmission lines

3. Military installation energy demand

4. State electricity prices

5. Local policy and regulatory environment

Table 1 summarizes the main results, sorted by the distance from the tribal lands to the installation. There is not sufficient information available to perform an economic analysis for different projects however, the distance is indicative of potential economic impact on the project. The average commercial electric rate for each state is also included as a proxy for the installation electric rates, however it is likely that the installation will pay a different rate. An economic analysis of proposed projects might change the list of sites. If a list of projects is not available, a straw-man project could be evaluated for each installation, assuming the same resource. This project would allow an economic assessment to include state incentives and utility rates.

\footnotetext{
${ }^{1}$ For more information on the renewable energy project development process, watch free on-demand webinars developed by the DOE Office of Indian Energy at https:/www.nterlearning.org/web/guest/course-details?cid=405.
} 
Table ES-1. Summary of Top 15 Reservations with Tribal Installation Energy Potential

\begin{tabular}{|c|c|c|c|c|}
\hline Tribe Name & Installation Name & $\begin{array}{l}\text { State } \\
\text { Electric } \\
\text { Rate } \\
(\$ / \mathrm{kWh})\end{array}$ & $\begin{array}{l}\text { Resources } \\
\text { Required to } \\
\text { Meet Load } \\
(\%)\end{array}$ & $\begin{array}{l}\text { Distance from } \\
\text { land to } \\
\text { Installation } \\
\text { (miles) }\end{array}$ \\
\hline Isleta Pueblo & Kirtland Air Force Base & 0.088 & $0.006 \%$ & 0.2 \\
\hline Cocopah & USMC Air Station-Yuma & 0.101 & $0.066 \%$ & 1.5 \\
\hline Quechan Tribe & Yuma Proving Ground & 0.101 & $0.006 \%$ & 2.5 \\
\hline $\begin{array}{l}\text { Ysleta Del Sur } \\
\text { Pueblo }\end{array}$ & Fort Bliss & 0.088 & $20.470 \%$ & 3.4 \\
\hline Tohono O'odham & Davis-Monthan Air Force Base & 0.101 & $0.012 \%$ & 4.8 \\
\hline $\begin{array}{l}\text { Santa Rosa } \\
\text { Rancheria }\end{array}$ & Lemoore Naval Air Station & 0.128 & $3.039 \%$ & 5.9 \\
\hline $\begin{array}{l}\text { Colorado River } \\
\text { Indian Tribes }\end{array}$ & Yuma Proving Ground & 0.101 & $0.001 \%$ & 5.9 \\
\hline Cochiti Pueblo & $\begin{array}{l}\text { New Mexico National Guard } \\
\text { Armory }\end{array}$ & 0.088 & $0.094 \%$ & 7.9 \\
\hline $\begin{array}{l}\text { Santo Domingo } \\
\text { Pueblo }\end{array}$ & $\begin{array}{l}\text { New Mexico National Guard } \\
\text { Armory }\end{array}$ & 0.088 & $0.069 \%$ & 8.3 \\
\hline $\begin{array}{l}\text { Pala Band of } \\
\text { Mission Indians }\end{array}$ & $\begin{array}{l}\text { Camp Pendleton Marine Corps } \\
\text { Base }\end{array}$ & 0.128 & $0.147 \%$ & 8.7 \\
\hline $\begin{array}{l}\text { Pechanga Band of } \\
\text { Luiseno Indians }\end{array}$ & $\begin{array}{l}\text { Camp Pendleton Marine Corps } \\
\text { Base }\end{array}$ & 0.128 & $0.365 \%$ & 8.7 \\
\hline Sandia Pueblo & Kirtland Air Force Base & 0.088 & $0.101 \%$ & 8.9 \\
\hline Mescalero Apache & White Sands Missile Range & 0.088 & $0.003 \%$ & 9.7 \\
\hline Pascua Yaqui & Davis-Monthan Air Force Base & 0.101 & $0.975 \%$ & 9.9 \\
\hline $\begin{array}{l}\text { Gila River Indian } \\
\text { Community }\end{array}$ & Luke Air Force Base & 0.101 & $0.003 \%$ & 10.0 \\
\hline
\end{tabular}

In addition to these factors that identify the potential for off-taker opportunities regarding renewable energy projects on tribal lands, there are several other factors that would influence actual development, including the military's procurement rules for energy and the strategy for land development.

Given the small number of potential sites identified through this analysis, it is possible that outreach to Tribes and associated bases to identify interest in a partnership may further limit the list to a more realistic group for further analysis. 


\section{Table of Contents}

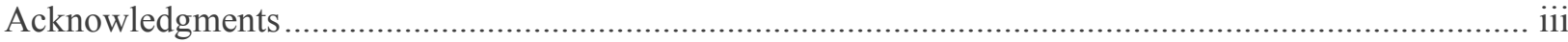

About the DOE Office of Indian Energy ................................................................................................... iii

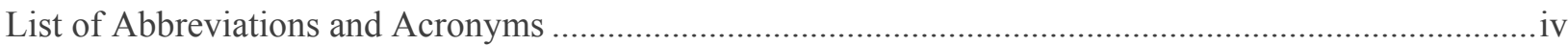

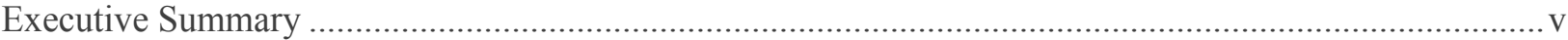

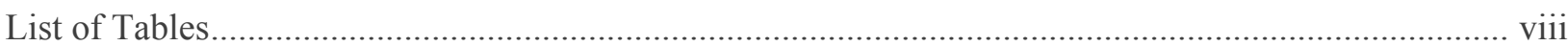

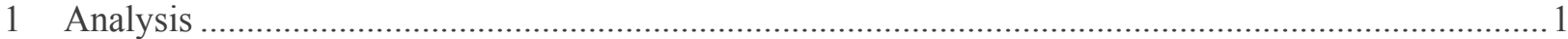

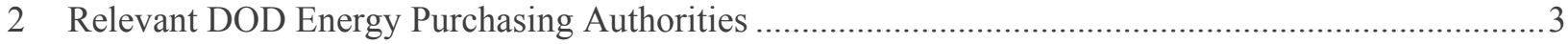

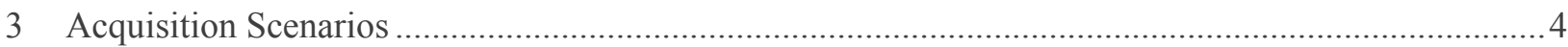

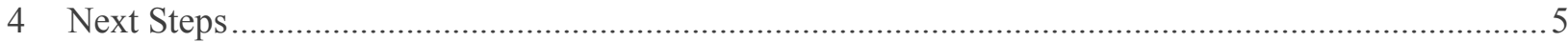

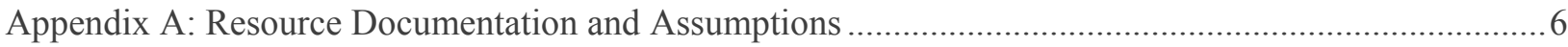

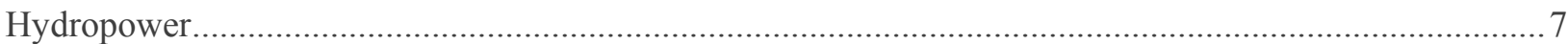

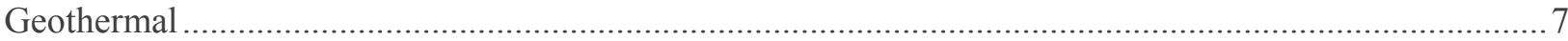

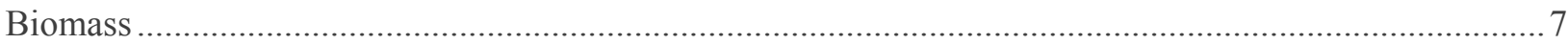

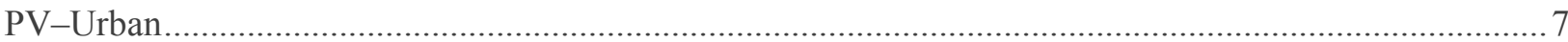

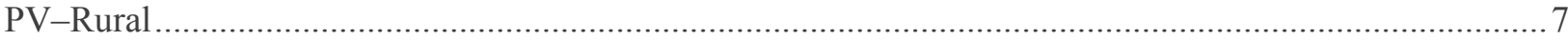

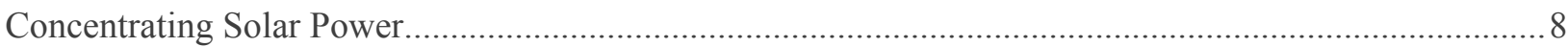

Wind

Appendix B: Links to DOD Branch Energy Offices........................................................................... 10

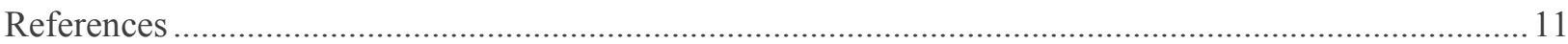




\section{List of Tables}

Table ES-1. Summary of Top 15 Reservations with Tribal Installation Energy Potential..........................vi

Table 1. Summary of Site Analysis Sorted by the Resources Required to Meet the Installation Energy Ratio.

Table 2. Summary of Tribal Renewable Energy Installed Capacity and Generation Potential by Technology..... 6

Table 3. Summary of Technical Resources in MMBtu for Each Tribe by Technology .9 


\section{Analysis}

This analysis builds on a geospatial analysis completed in November 2012 identifying 53 reservations within 10 miles of military bases (DOE 2012). The data used in that analysis are the 2012 Homeland Security Infrastructure Protection geospatial dataset listing military bases and the NREL-developed technical potential for renewable energy on tribal lands dataset (Lopez et al. 2012). This analysis builds on those findings by further refining the list of potential opportunity sites to 15 reservations (Table 1) based on three additional factors:

1. The resources required to meet the installation load. This metric is the percentage of total technical potential resource that would need to be developed in order to meet $100 \%$ of the energy load at the listed U.S. Department of Defense (DOD) installation site. This metric provides a high-level screen for estimating development requirements. Other information, such as actual utility rates, project technology, and size of project, would be required to provide an economic assessment.

2. Military installation energy demand. Energy consumption for the installations was taken from the DOD Annual Energy Management Report (Department of Defense 2012). The 2012 report contains the total energy in million British thermal units (MMBtu) delivered to each installation within the DOD for fiscal year (FY) 2010 and FY 2011.

3. Local policy and regulatory environment. An analysis of the renewable energy markets is indicative of the demand for renewable energy, and hence the appetite for new projects in each state. This analysis uses an analysis of state renewable portfolio standards (RPS) in the Western Electricity Coordinating Council (WECC) region (Haase, Billman, and Gelman 2012) and RPS data from the Database of State Incentives for Renewable Energy (DSIRE) website for states outside the WECC area. ${ }^{2}$ All of the potential development summarized in Table 1 occurs in states in which the RPS has not been met, indicating a potentially favorable market for new renewable energy projects.

To further define the context in which the partnerships might be appealing, the following additional information is included in Table 1:

1. Proximity to transmission lines. The transmission proximity figure is based on the total capacity of all transmission lines $(\mathrm{kV})$ within 10 miles of the tribal lands. Only Tribes and military bases with close proximity transmission lines are included in these results. Note that the available transmission capacity is not estimated but could be included in further refinements of the analysis.

2. State energy prices. The average commercial energy rate for each state was taken from the U.S. Energy Information Administration website (EIA 2012). These energy rates were used as a proxy for site electric rates and are included here to indicate the relative cost of electricity for the installations. Because the installation utility rates are likely to be different that the state rates, these number were not used in the final sorting analysis.

2 Database of State Incentives for Renewable Energy (DSIRE), http:/www.dsireusa.org/. 


\section{Table 1. Summary of Site Analysis Sorted by the Resources Required to Meet the Installation Energy Ratio}

\begin{tabular}{|c|c|c|c|c|}
\hline Tribe Name & Installation Name & $\begin{array}{l}\text { State } \\
\text { Electric } \\
\text { Rate } \\
(\$ / \mathrm{kWh})\end{array}$ & $\begin{array}{l}\text { Resources } \\
\text { Required to } \\
\text { Meet Load } \\
(\%)\end{array}$ & $\begin{array}{l}\text { Distance from } \\
\text { land to } \\
\text { Installation } \\
\text { (miles) }\end{array}$ \\
\hline Isleta Pueblo & Kirtland Air Force Base & 0.088 & $0.006 \%$ & 0.2 \\
\hline Cocopah & USMC Air Station-Yuma & 0.101 & $0.066 \%$ & 1.5 \\
\hline Quechan Tribe & Yuma Proving Ground & 0.101 & $0.006 \%$ & 2.5 \\
\hline $\begin{array}{l}\text { Ysleta Del Sur } \\
\text { Pueblo }\end{array}$ & Fort Bliss & 0.088 & $20.470 \%$ & 3.4 \\
\hline Tohono O'odham & Davis-Monthan Air Force Base & 0.101 & $0.012 \%$ & 4.8 \\
\hline $\begin{array}{l}\text { Santa Rosa } \\
\text { Rancheria }\end{array}$ & Lemoore Naval Air Station & 0.128 & $3.039 \%$ & 5.9 \\
\hline $\begin{array}{l}\text { Colorado River } \\
\text { Indian Tribes }\end{array}$ & Yuma Proving Ground & 0.101 & $0.001 \%$ & 5.9 \\
\hline Cochiti Pueblo & $\begin{array}{l}\text { New Mexico National Guard } \\
\text { Armory }\end{array}$ & 0.088 & $0.094 \%$ & 7.9 \\
\hline $\begin{array}{l}\text { Santo Domingo } \\
\text { Pueblo }\end{array}$ & $\begin{array}{l}\text { New Mexico National Guard } \\
\text { Armory }\end{array}$ & 0.088 & $0.069 \%$ & 8.3 \\
\hline $\begin{array}{l}\text { Pala Band of } \\
\text { Mission Indians }\end{array}$ & $\begin{array}{l}\text { Camp Pendleton Marine Corps } \\
\text { Base }\end{array}$ & 0.128 & $0.147 \%$ & 8.7 \\
\hline $\begin{array}{l}\text { Pechanga Band of } \\
\text { Luiseno Indians }\end{array}$ & $\begin{array}{l}\text { Camp Pendleton Marine Corps } \\
\text { Base }\end{array}$ & 0.128 & $0.365 \%$ & 8.7 \\
\hline Sandia Pueblo & Kirtland Air Force Base & 0.088 & $0.101 \%$ & 8.9 \\
\hline Mescalero Apache & White Sands Missile Range & 0.088 & $0.003 \%$ & 9.7 \\
\hline Pascua Yaqui & Davis-Monthan Air Force Base & 0.101 & $0.975 \%$ & 9.9 \\
\hline $\begin{array}{l}\text { Gila River Indian } \\
\text { Community }\end{array}$ & Luke Air Force Base & 0.101 & $0.003 \%$ & 10.0 \\
\hline
\end{tabular}




\section{Relevant DOD Energy Purchasing Authorities}

U.S. Code Title $10 \S 2922$ A "Contracts for energy or fuel for military installations" allows military installations to enter into contracts of up to 30 years for provision and operation of energy production facilities. The energy production facilities may be on military installations or on private property. The contracts must be approved by the secretary of defense, and contract costs may be paid for with annual appropriations.

This purchasing authority allows a military installation to enter into energy purchase contracts, such as a power purchase agreement for up to 30 years. This extended time can make the project more costeffective and reduce the risk to the government in purchasing energy generated from renewable resources. 


\section{Acquisition Scenarios}

Several acquisition scenarios were developed to illustrate different arrangements between the Tribes and the installations:

- The Tribe could build and maintain the renewable generation systems and sell power to installation. This requires the Tribe to have a sufficiently skilled workforce to develop and maintain the project or a partnership with an external developer. This scenario also allows for the Tribe to use energy from the system if enough additional capacity is built.

- The installation could lease land from the Tribe to build the renewable generation systems. This requires that the military installation has a sufficiently skilled workforce to develop and maintain the project or a partnership with an external developer.

- A developer could lease land from the Tribe and develop the renewable generation system. In this case, the Tribe and installation could both be off-takers from the system if sufficient resources and demand exist.

It should be noted that focusing exclusively on DOD installations as off-takers could be limiting the scope of tribal renewable energy development. The development scenarios listed above could also apply in situations where a utility is the off-taker.

For more information on renewable energy project development opportunities and process, access free ondemand webinars developed by the DOE Office of Indian Energy at https://www.nterlearning.org/web/guest/course-details?cid=405. 


\section{Next Steps}

The 15 sites identified in this report represent the outcomes of a screening-level analysis. A more detailed analysis is required to further identify good potential sites. Potential next steps include:

- Convene a meeting with tribal and DOD leaders to gauge interest in developing projects.

- Develop an economic analysis to identify projects that would meet grid parity in costs. This is an important next step because the DOD will not purchase energy with costs greater than utility rates. If no projects exist, this could be accomplished by analyzing the costs and incentives for a strawman project in each state, e.g, the levelized cost of energy for a 100-kW PV system would be $\$ \mathrm{X} / \mathrm{kWh}$ in New Mexico and $\$ Y / \mathrm{kWh}$ in Arizona.

- Develop a more detailed analysis for resource development on the tribal lands. This analysis would include conducting a more detailed study of resource potential as well as identifying specific sites for project deployment. Of course, consideration should be given to culturally significant and sacred areas to ensure that they remain undisturbed. This analysis could also assist the Tribes in understanding which resources should receive the most development attention.

- Develop a grid study for each proposed project in order to identify available capacity within the transmission and distribution networks that serve the tribal lands and installations. 


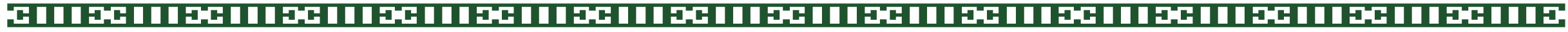

\section{Appendix A: Resource Documentation and Assumptions}

Table 2 summarizes the total technical potential and generating capacity for the tribal lands (Doris, Lopez, and Beckley 2013). The details of these estimates follow the table. Table 3 (Doris, Lopez, and Beckley 2013) contains the total technical estimates, in megawatt-hours, for each generation source for the tribal lands identified in Table 1.

Table 2. Summary of Tribal Renewable Energy Installed Capacity and Generation Potential by Technology

\begin{tabular}{|c|c|c|c|c|c|c|}
\hline Technology & $\begin{array}{l}\text { Tribal } \\
\text { Capacity } \\
\text { Potential } \\
(\mathrm{MW})\end{array}$ & $\begin{array}{l}\text { Tribal Generation } \\
\text { Potentiala (MWh) }\end{array}$ & $\begin{array}{l}\text { National } \\
\text { Capacity } \\
\text { Potentiala (MW) }\end{array}$ & $\begin{array}{l}\text { National Generation } \\
\text { Potentiala (MWh) }\end{array}$ & $\begin{array}{l}\% \text { of } \\
\text { National } \\
\text { Capacity }\end{array}$ & $\begin{array}{l}\% \text { of } \\
\text { National } \\
\text { Generation }\end{array}$ \\
\hline $\begin{array}{l}\text { Wind }(80 \mathrm{~m} \text { ht, }>=30 \% \\
\text { GCF) }\end{array}$ & 381,946 & $1,105,178,858$ & $10,954,759$ & $32,784,004,656$ & $3.5 \%$ & $3.4 \%$ \\
\hline $\begin{array}{l}\text { Solar Photovoltaic (PV) } \\
\text { (Utility-Scale, Rural) }\end{array}$ & $4,494,841$ & $9,342,469,810$ & $152,973,829$ & $280,613,216,903$ & $2.9 \%$ & $3.3 \%$ \\
\hline $\begin{array}{l}\text { Solar PV (Utility-Scale, } \\
\text { Urban) }\end{array}$ & 7,222 & $15,368,543$ & $1,217,699$ & $2,231,693,746$ & $0.6 \%$ & $0.7 \%$ \\
\hline $\begin{array}{l}\text { Concentrating Solar } \\
\text { Power (CSP) }\end{array}$ & $1,818,185$ & $6,139,851,743$ & $38,066,401$ & $116,146,244,587$ & $4.8 \%$ & $5.3 \%$ \\
\hline $\begin{array}{l}\text { Geothermal (Enhanced } \\
\text { Geothermal System) }\end{array}$ & 763,252 & $6,017,487,000$ & $3,975,735$ & $31,344,696,024$ & $19.2 \%$ & $19.2 \%$ \\
\hline $\begin{array}{l}\text { Geothermal } \\
\text { (Hydrothermal) }\end{array}$ & 641 & $5,050,724$ & 30,033 & $236,780,000$ & $2.1 \%$ & $2.1 \%$ \\
\hline Biomass (Solid) & 551 & $4,340,642$ & 50,707 & $399,774,091$ & $1.1 \%$ & $1.1 \%$ \\
\hline Biomass (Gaseous) & 85 & 673,465 & 11,232 & $88,551,445$ & $0.8 \%$ & $0.8 \%$ \\
\hline Hydropower & 1,687 & $13,302,352$ & 60,000 & $258,953,000$ & $2.8 \%$ & $5.1 \%$ \\
\hline Totala & $7,468,411$ & $22,643,723,138$ & $207,340,394$ & $464,103,914,451$ & $3.6 \%$ & $4.9 \%$ \\
\hline
\end{tabular}

${ }^{a}$ Technical potential calculated for each technology individually; does not account for overlap (i.e., the same land area may be identified with potential for wind and solar, and would be counted twice in the total). Some technologies may be compatible with mutual development. 


\section{Hydropower}

Resource estimates were produced by the Idaho National Laboratory and are published in the Feasibility Assessment of the Water Energy Resources of the United States for New Low Power and Small Hydro Classes of Hydroelectric Plants (www1.eere.energy.gov/water/pdfs/doewater-11263.pdf).

\section{Geothermal}

The geothermal resource total includes enhanced geothermal potential and unidentified hydrothermal potential. Identified hydrothermal potential is derived from data produced by the 2008 Geothermal Resource Assessment produced by the U.S. Geological Survey (http://pubs.usgs.gov/fs/2008/3082/) and NREL (http://www.nrel.gov/docs/fy10osti/47458.pdf). Enhanced geothermal system potential is derived from data representing temperatures 3-10 kilometers below the Earth's surface. This data was produced by the Southern Methodist University and NREL (http:/www.nrel.gov/docs/fy10osti/47458.pdf) and does not include Alaska and Hawaii. A 90\% system operating capacity factor is assumed for both technologies. Federally protected lands (national parks, wilderness, etc.) are excluded in this analysis.

\section{Biomass}

Solid residues are represented by forest, crop, primary mill, and urban wood residues. Generation is estimated assuming 1.1 megawatt-hour (MWh)/bone dry ton of residue. Gaseous residues are represented by landfill and domestic wastewater residues. Generation is estimated assuming $4.7 \mathrm{MWh} /$ tonne of methane produced by the residues. The solid biomass residues are defined statistically at the county level. Forest, crop, and urban residues are spatially refined by limiting the county level totals to those land cover types within the county. The tribal residue total is calculated based on the proportion of these land cover types falling within the tribal land boundary. Landfill locations are point-specific locations, and only points falling within the tribal boundaries are included. Domestic wastewater residues are estimated based on county populations and are apportioned to the tribal area proportionally by area overlap.

\section{PV-Urban}

Resource areas are limited to urban areas. Estimates assume installed capacity of $48 \mathrm{MW} / \mathrm{square}$ kilometers $\left(\mathrm{km}^{2}\right)$, and annual capacity factors calculated from the National Solar Radiation Database Typical Meteorological Year 3 (TMY3) dataset. The analysis utilizes satellite modeled data from the State University of New York (SUNY) and NREL of a 1-axis tracking collector facing the equator with 0 degree tilt, representing 1998-2005. Areas with slope $>3 \%$, parks, landmarks, forested areas, wetlands, and impervious surfaces are excluded. Remaining areas are further filtered to eliminate areas $<0.018 \mathrm{~km}^{2}$ in size.

\section{PV-Rural}

Assumes installed capacity of $48 \mathrm{MW} / \mathrm{km}^{2}$ and annual capacity factors calculated from the National Solar Radiation Database Typical Meteorological Year 3 (TMY3) dataset. The analysis utilizes satellite modeled data from SUNY/NREL, of 1-axis tracking collector facing the equator with 0 degree tilt, representing 1998-2005. Areas with slope $>3 \%$, urban areas, water features, wetlands, and protected federal lands are excluded. Remaining areas are further filtered to eliminate areas $<1 \mathrm{~km}^{2}$ in size. 


\section{Concentrating Solar Power}

CSP estimates are for trough systems with six hours of storage and dry cooling. Estimates assume installed capacity of $32.895 \mathrm{MW} / \mathrm{km}^{2}$ and annual capacity factors between $31.5 \%$ and $44.8 \%$ for resource areas $>5 \mathrm{kWh} / \mathrm{m}^{2} /$ day annual average resource. The analysis utilizes satellite modeled data from SUNY/NREL, of direct normal representing 1998-2005. The resource has been filtered to eliminate resource $<5 \mathrm{kWh} / \mathrm{m}^{2} /$ day annual average, areas with slope $>3 \%$, urban areas, water features, wetlands, and federally protected lands (national parks, wilderness, etc.) Remaining areas are further filtered to eliminate areas $<1 \mathrm{~km}^{2}$ in size.

\section{Wind}

These estimates show, for each of the tribal areas in the contiguous United States, the windy land area with a gross capacity factor (without losses) of 30\% and greater at 80 meters (m) and $100 \mathrm{~m}$ above ground and the wind energy potential that could be possible from development of the "available" windy land area after exclusions. The "installed capacity" shows the potential MW of rated capacity that could be installed on the available windy land area, and the "annual generation" shows annual wind energy generation in MWh that could be produced from the installed capacity. AWS Truewind, LLC developed the wind resource data for windNavigator (http://navigator.awstruewind.com) with a spatial resolution of $200 \mathrm{~m}$. NREL produced the estimates of windy land area and windy energy potential, including filtering the estimates to exclude areas unlikely to be developed, such as wilderness areas, parks, urban areas, and water features.

Contact the following people for more information on resource estimates:

- Hydropower, Rural PV, Urban PV, CSP: Anthony Lopez, (anthony.lopez@nrel.gov)

- Biomass: Anelia Milbrandt (anelia.milbrandt@nrel.gov) or Anthony Lopez (anthony.lopez@nrel.gov)

- Geothermal: Billy Roberts (billy.roberts@nrel.gov)

- Wind: Donna Heimiller (donna.heimiller@nrel.gov) 
Military Base Offtaker Opportunities for Tribal Renewable Energy Projects

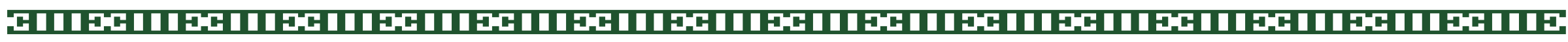

Table 3. Summary of Technical Resources in MWh for Each Tribe by Technology

\begin{tabular}{|c|c|c|c|c|c|c|c|c|}
\hline Tribe Name & Hydro & Geothermal & Biomass & Urban PV & Rural PV & CSP & Wind & Total \\
\hline Cochiti Pueblo & 46,228 & $6,425,000$ & 71 & 0 & $6,577,674$ & $6,560,708$ & 0 & $19,609,681$ \\
\hline Cocopah & 0 & 355,000 & 26,564 & 97,644 & $1,742,699$ & $2,374,270$ & 0 & $4,596,177$ \\
\hline $\begin{array}{l}\text { Colorado River } \\
\text { Indian Tribes }\end{array}$ & 191,709 & $35,588,000$ & 17,848 & 120,325 & $83,559,429$ & $87,227,378$ & 0 & $206,704,690$ \\
\hline Quechan Tribe & 22,195 & $5,558,000$ & 2,525 & 190,740 & $13,073,254$ & $13,842,225$ & 96,539 & $32,785,478$ \\
\hline $\begin{array}{l}\text { Gila River } \\
\text { Indian } \\
\text { Community }\end{array}$ & 86,377 & $35,265,000$ & 27,382 & 42,358 & $123,657,341$ & $123,184,942$ & 894 & $282,264,294$ \\
\hline Isleta Pueblo & 15,270 & $23,479,000$ & 730 & 174,092 & $54,799,937$ & $54,658,370$ & 52,183 & $133,179,581$ \\
\hline $\begin{array}{l}\text { Mescalero } \\
\text { Apache }\end{array}$ & 13,853 & $47,667,000$ & 10,099 & H, nol & $4,115,939$ & $4,105,309$ & $4,985,000$ & $60,897,201$ \\
\hline $\begin{array}{l}\text { Pala Band of } \\
\text { Mission Indians }\end{array}$ & 5,280 & 986,000 & 12 & 0 & 202,950 & 169,364 & 0 & $1,363,606$ \\
\hline Pascua Yaqui & 0 & 118,000 & 425 & 278,902 & 23,354 & 23,261 & 0 & 443,942 \\
\hline $\begin{array}{l}\text { Pechanga Band } \\
\text { of Luiseno } \\
\text { Indians }\end{array}$ & 0 & 363,000 & 251 & 42,684 & 75,381 & 62,906 & 0 & 544,223 \\
\hline $\begin{array}{l}\text { Tohono } \\
\text { O'odham }\end{array}$ & 4,748 & $9,193,000$ & 868 & 384,742 & $23,247,107$ & $23,819,813$ & 0 & $56,650,278$ \\
\hline Sandia Pueblo & 3,185 & $2,712,000$ & 649 & 326,301 & $1,875,667$ & $1,870,825$ & 0 & $6,788,627$ \\
\hline $\begin{array}{l}\text { Santa Rosa } \\
\text { Rancheria }\end{array}$ & 0 & 16,000 & 19 & 0 & 51,461 & 42,945 & 0 & 110,424 \\
\hline $\begin{array}{l}\text { Santo Domingo } \\
\text { Pueblo }\end{array}$ & 19,569 & $8,562,000$ & 758 & 611,928 & $8,519,004$ & $8,497,031$ & 0 & $26,210,290$ \\
\hline $\begin{array}{l}\text { Ysleta Del Sur } \\
\text { Pueblo }\end{array}$ & 0 & 8,000 & 16 & 0 & 28,115 & 33,798 & 1,084 & 71,014 \\
\hline
\end{tabular}




\section{Appendix B: Links to DOD Branch Energy Offices}

The following links provide more information about renewable energy acquisition within the DOD.

- U.S Army Energy Initiatives Task Force

○ http://www.armyeitf.com/

- U.S. Air Force Energy Initiatives

○ http://www.af.mil/energyinitiatives/index.asp

- U.S. Navy Task Force Energy

○ http:/greenfleet.dodlive.mil/energy/task-force-energy/ 


\section{References}

Department of Defense Annual Energy Management Report Fiscal Year 2011. (2012). Office of the Deputy Under Secretary of Defense (Installations and Environment). Accessed November 11, 2012: http://www.acq.osd.mil/ie/energy/library/FY.2011.AEMR.pdf.

DOE Office of Indian Energy: Leveraging Tribal Resources to Support Department of Defense Strategic Energy Goals (Fact Sheet). (2012). Department of Indian Energy Policy and Programs. DOE/IE-0009. Golden, CO: National Renewable Energy Laboratory. http://www.nrel.gov/docs/fy13osti/56304.pdf.

Doris, E.; Lopez, A.; and Beckley, D. (2013). Geospatial Analysis of Renewable Energy Technical Potential on Tribal Lands. NREL/ TP-7A30-56641. Golden, CO: National Renewable Energy Laboratory. http://www.nrel.gov/docs/fy13osti/56641.pdf.

Haase, S; Billman, L.; and Gelman, R. (2012). Western Region Renewable Energy Markets: Implications for the Bureau of Land Management. NREL/TP-6A20-53540. Golden, CO: National Renewable Energy Laboratory. http://www.nrel.gov/docs/fy12osti/53540.pdf.

Lopez, A.; Roberts, B.; Heimiller, D., Blair, N., and Porro, G. (2012). U.S. Renewable Energy Technical Potentials: A GIS-Based Analysis. NREL/TP-6A20-51946. Golden, CO: National Renewable Energy Laboratory. http://www.nrel.gov/docs/fy12osti/51946.pdf.

U.S. Energy Information Administration (EIA). (2012). "Electricity.” Accessed October 15, 2012: http://www.eia.gov/electricity/data.cfm\#sales. 